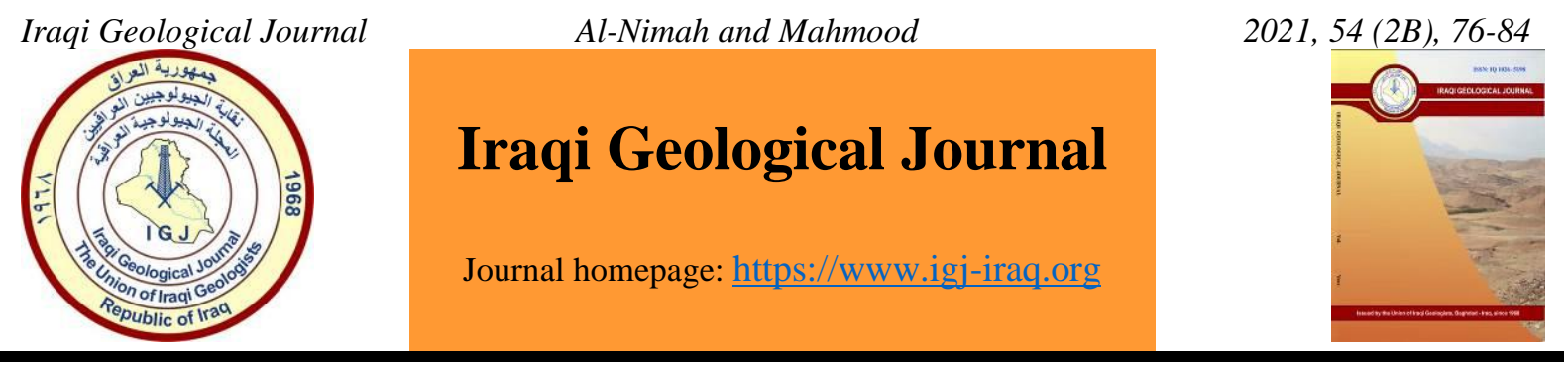

\title{
The Effect of Oil Contamination on some Geotechnical Properties of West Qurna Oilfield Soils at Basrah, Southern Iraq
}

\author{
Ahmed K. Al-Nimah ${ }^{1}$ and Raid A. Mahmood ${ }^{1, *}$ \\ ${ }^{1}$ Department of Geology, College of Science, University of Basrah, Basrah, Iraq \\ * Correspondence: ahmedkadem81@yahoo.com
}

Received: 28 February 2021; Accepted: 15 June 2021; Published: 31 August 2021

\begin{abstract}
Oil contamination in soils causes several geotechnical problems that must be considered during construction. The contamination occurs due to oil seepage which could happen during oil explorations and production processes or oil transportation. The site of West Qurna oilfield in Basrah was selected for this study because it has witnessed oil seepages many times. In order to study the significant impact on geotechnical properties of soils in the West Qurna site, as uncontaminated bulk soil sample was taken at a depth of $1 \mathrm{~m}$, and crude oil was added at weight ratios of 2, 4, 6, 8, and $10 \%$. Laboratory tests were performed on all samples; these tests included particle size distribution, moisture content, Atterberg's limits, consolidation, unconfined compressive strength, and water absorption. The results show that soil at the West Qurna site is clayey silt with little sand and the moisture content is $29.21 \%$. The values of liquid limit and plasticity index were gradually decreased, while the plastic limit was increased with increasing of crude oil in the soil of study. There was an increase in consolidation coefficients [compressive index, swelling index, pre-consolidation pressure, and coefficient of consolidation] with an increase in the percentages of crude oil in the soil. The results also show that there was a decrease in the values of unconfined compressive strength and absorption of water as the crude oil was increased in the soil.
\end{abstract}

Keywords: Oil contamination; Basrah soil; Geotechnical properties; West Qurna soil; Grain size analysis.

\section{Introduction}

Oil contamination is one of the most dangerous pollutants that caused problems in the ecosystem (Awadh, 2015). Large quantities of oil products enter the environment in various ways through damaged pipelines and reservoirs, tanker accidents, offshore oil production, and natural oil spills (Alhassan and Fagge, 2013), which affects the safety and foundations of engineering facilities. Contamination affects the geotechnical properties of the soil, such as strength, permeability, porosity, and bearing capacity, which makes it unsuitable for engineering use (Breivik and Burgess, 2013). The great problem is when the effects of contamination reach the bearing strata of the foundation, causing a decrease in its strength and deformations of the foundation, which may cause a collapse of the building (Sanjay et al., 2003).

Basrah is characterized by abundant of oil production (Awadeesian et al., 2018; Al-Mimar et al., 2018; Awadh et al., 2019). When designing any engineering facility in an oilfield site, it is necessary to

DOI: $\underline{10.46717 / \text { igj.54.2B.7Ms-2021-08-27 }}$ 
know the geotechnical properties of the soil and the effect of contaminant material from different sources and the surrounding environmental conditions on them (Jamal and Shahalam, 2002).

Many researchers in Iraq and the world have studied the effects of oil contamination on the geotechnical properties of the soil. For example, Meegoda and Ratnaweera (1994) observed an increase in settlement of oily soil compared to the clean soil as the particles can slip and slid together due to the lubrication. Al-Sanad et al. (1995) studied the effect of crude oil contamination on the angle of internal friction in sandy soils, and observed that the angle decreases with the increase of oil contamination. AlAmoudi and Abduljauwad, (1995) noticed that the specific gravity of soil slightly decreases with an increase in the percentage of crude oil due to the contamination by organic materials which have low density. Hahn (2005) noticed that the high viscosity of oil leads to a decrease in the permeability coefficient of the oiled soil due to the blocking of the pores and reducing the percentage of voids ratio. Hassan et al. (2005) studied the relationship between oil content and Californian Bearing Ratio, and they observed an increase in the CBR ratio of submerged and non-submerged soil samples from contaminated soil with an increase of $6 \%$ and $8 \%$ of crude oil. Rahman et al. (2010) found that the presence of oil in clayey soil reduces the liquid limit and plasticity index, and it is believed that the presence of oil in large quantities leads to block the soil pores, which prevents the process of ion exchange between water and soil particles. Nazir (2011) studied the effect of crude oil on unconfined compressive strength. The results showed that the compressive strength of the contaminated soil decreased compared to noncontaminated soil. Kermani and Ebadi (2012) explained that increasing the crude oil content reduces the optimum water content because the oil substance acts as a lubricant for the granules. Akinwumi et al. (2014) found that increasing oil content in the soil reduces the maximum dry density and prevents the water from interacting with the soil particles. This research aims to study the effect of oil contamination on some geotechnical properties of the soil by adding different percentages of crude oil to a natural soil brought from the site of West Qurna oilfield in Basrah, southern Iraq. The site is located at the intersection of longitude $30^{\circ} 53^{\prime} 7^{\prime \prime} \mathrm{N}$ and latitude $47^{\circ} 17^{\prime} 27^{\prime \prime} \mathrm{E}$, as shown in Fig.1.

\section{Materials and Methods}

To achieve the objective of this study, the West Qurna oilfield site was visited in Qurna district and uncontaminated bulk soil sample was taken at a depth of $1 \mathrm{~m}$ of the site. The sample was stored in tightly sealed nylon bags and transported to the laboratory to conduct the geotechnical tests that described below._Crude oil used in this study brought from West Qurna oil field. Its properties were examined at the College of Engineering, Petroleum Engineering Department/ University of Basrah. The results show that the viscosity is $91.84 \mathrm{cp}$ at $40{ }^{\circ} \mathrm{C}$, API is 25.5 , density is $0.9126 \mathrm{~g} / \mathrm{cm} 3$ at $40{ }^{\circ} \mathrm{C}$ and the specific gravity is 0.9142 .The bulk sample was divided into 26 samples to use them in geotechnical tests as follow:

a- Particle size distribution: This test was performed using dry sieving and hydrometer method on the soil sample in accordance to ASTM D-421, D-422. The test was accomplished at Basrah construction laboratory.

b- Moisture content (M.C): This test was carried out according to ASTM D-2216-05, in the laboratory of Geology Department, University of Basrah.

c- Atterberg's limits: To calculate Atterberg's limits, a soil sample was taken from West Qurna oilfield site in its natural state. The sample was dried at $60^{\circ} \mathrm{C}$, and then passed through a sieve of No.4 $(0.425 \mathrm{~mm})$. Five other samples were prepared by adding five weight ratios of crude oil, including 2, 4, 6,8 and $10 \%$, and left for 24 hours to mature the mixture. These tests were run according to ASTM D4318 at Basrah construction laboratory. 


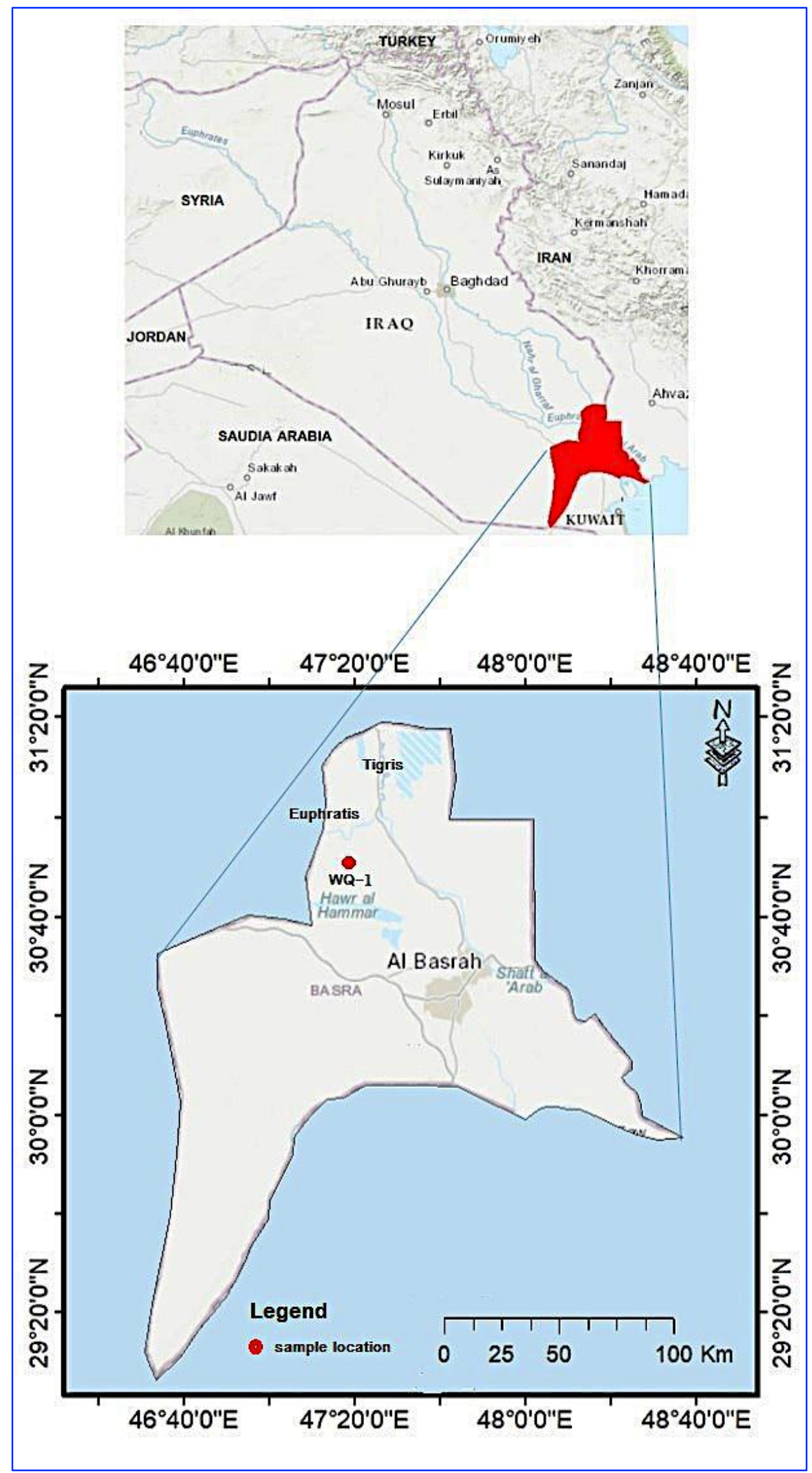

Fig. 1. Map of Basrah and location of the study area 
d- Consolidation test: A remolded sample from the first meter of West Qurna oilfield site was prepared with a cylindrical shape of $7.5 \mathrm{~cm}$ in diameter and $2 \mathrm{~cm}$ in height according to ASTM D-2435. Five other remolded samples were prepared by adding five weight ratios of crude oil, including 2, 4, 6, 8 , and $10 \%$, and left for 24 hours to mature the mixture. This teste was conducted at Basrah construction laboratory.

e- Unconfined compressive strength test: A remolded cylindrical sample of $3.8 \mathrm{~cm}$ (Diameter) and $7.6 \mathrm{~cm}$ (Height) was prepared according to the specification ASTM D-1883. Five more remolded samples were prepared for the test by adding five weight ratios of the crude oil, including 2, 4, 6, 8 and $10 \%$, and then left for 24 hours to mature the mixture. The unconfined compressive strength tests were carried out according to ASTM D-2166 at Basrah construction laboratory.

f- Rapid absorption test: A cylindrical soil sample was prepared in its natural condition with a dimension of $15 \times 7.5 \mathrm{~cm}$ by the method of preparing samples in Californian Bearing Ratio test according to ASTM D-1883. Five more samples were prepared by adding crude oil at weight ratio 2, 4, 6, 8 and 10\%. The test was carried out according to BS.1377: 1975 at the laboratory of Geology Department, University of Basrah.

\section{Results and Discussion}

\subsection{Grain Size Analysis}

The results of the grain size analysis of the West Qurna oilfield natural soil sample show that the percentage of sand is $11 \%$, silt is $64 \%$ and clay is $25 \%$ (Table 1). Therefore, the soil is described as clayey silt with little sand. Basrah is located in the southern part of Iraq, covered with recent sediments that are typically formed from quaternary deposits extending from Pleistocene to Holocene Epoch, these deposits had a clay-silt texture, and transported by Tigris, Euphrates and Shatt Al-Arab rivers in addition to Aeolian deposits transported by wind and dust storm (Al-Khalf and Al-Saad, 2019). It represents mixed environments between the freshwater and brackish water (Al-Jaberi and Mahdi, 2020).

Table 1. Grain size analysis of West Qurna oilfield site soil

\begin{tabular}{ccc}
\hline Sand\% & Silt \% & Clay \% \\
\hline 11 & 64 & 25 \\
\hline
\end{tabular}

\subsection{Moisture Content}

The results show that the moisture content of West Qurna oilfield soil sample is $29.21 \%$, which considers as a high percentage due to its proximity to the general downstream river, and the ability of fine soils to absorb and retain water. Water in cohesive soil affects its geotechnical properties, such as shrinkage, swelling, and bearing capacity (Seed et al., 1962). The moisture content has a major role in reducing cohesion and internal friction angle and thus reducing the strength of the soil (Scott, 1968). The increase in the natural water content leads to increase in compression index) Luan et al.,2021).

\subsection{Atterberg Limits}

The result of the Atterberg limits tests is shown in Fig. 2. The value of liquid limit for natural soil is $46 \%$ and began to decrease with the increase of the crude oil content, reaching $42 \%$ and $43 \%$ when adding oil by $6 \%$ and $8 \%$ respectively. The value of the plastic limit of the natural soil is $20 \%$, it increased to $28 \%$ when the oil content was increased by $2 \%$, and become $29 \%, 32 \%$ when adding $6 \%$ and $10 \%$ of crude oil respectively. As well as, the plasticity index of natural soils is $28 \%$ and decreases to $13 \%$ and $10 \%$ with the addition of $8 \%$ and $10 \%$ of crude oil. 


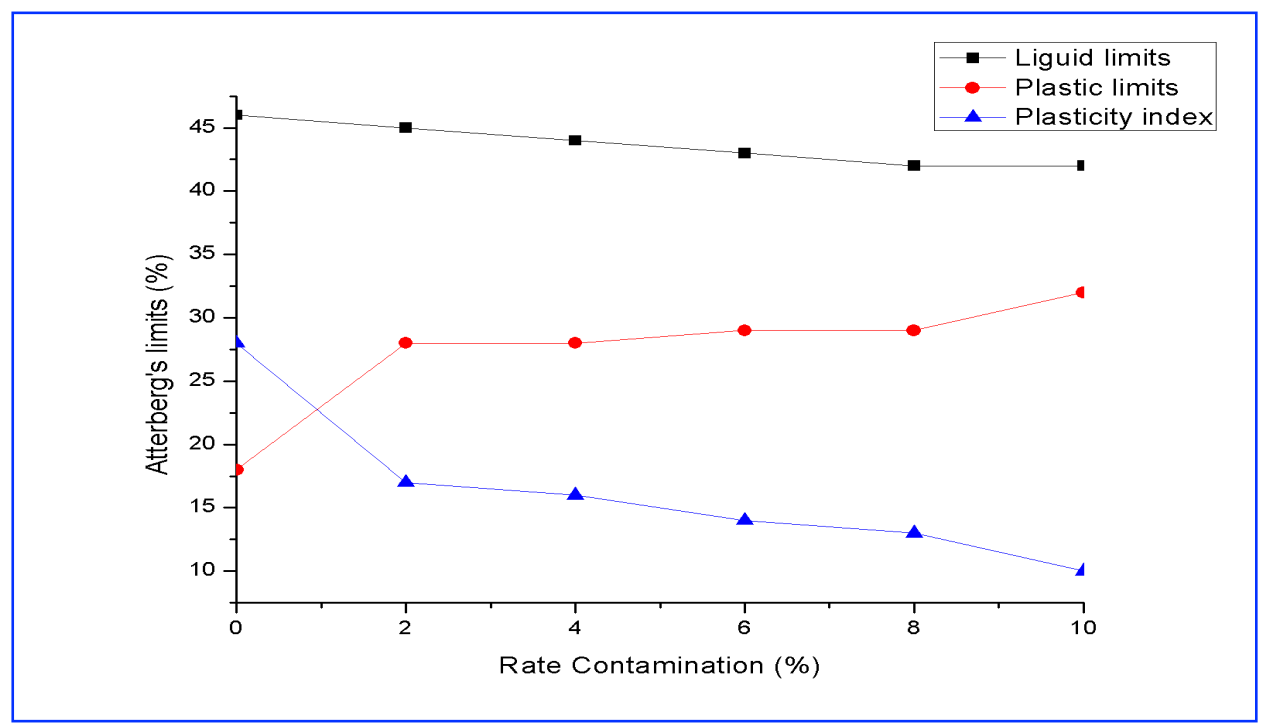

Fig.2. The values of liquid limit, plastic limit and plasticity index of West Qurna oilfield site soil before and after adding crude oil

The decrease in liquid limit may attribute to the fact that the presence of water which leads to interact it with the clay grains and forms water layers around them. However, when adding crude oil, it covers the surface of particles and prevents the formation of these layers. Hence the soil needs more water to reach the plasticity state. The natural soil under investigation is classified as clayey soil with low plasticity (CL) according to plasticity diagram as illustrated in Fig. 3; however, when crude oil added in different proportions to the samples, the soil classification changes to low plasticity silty soils (ML). This change on soil classification is due to the different values of liquid limit and plasticity index beside the change of the grain size causes by the adhesion of particles together after adding crude oil ratio to them.

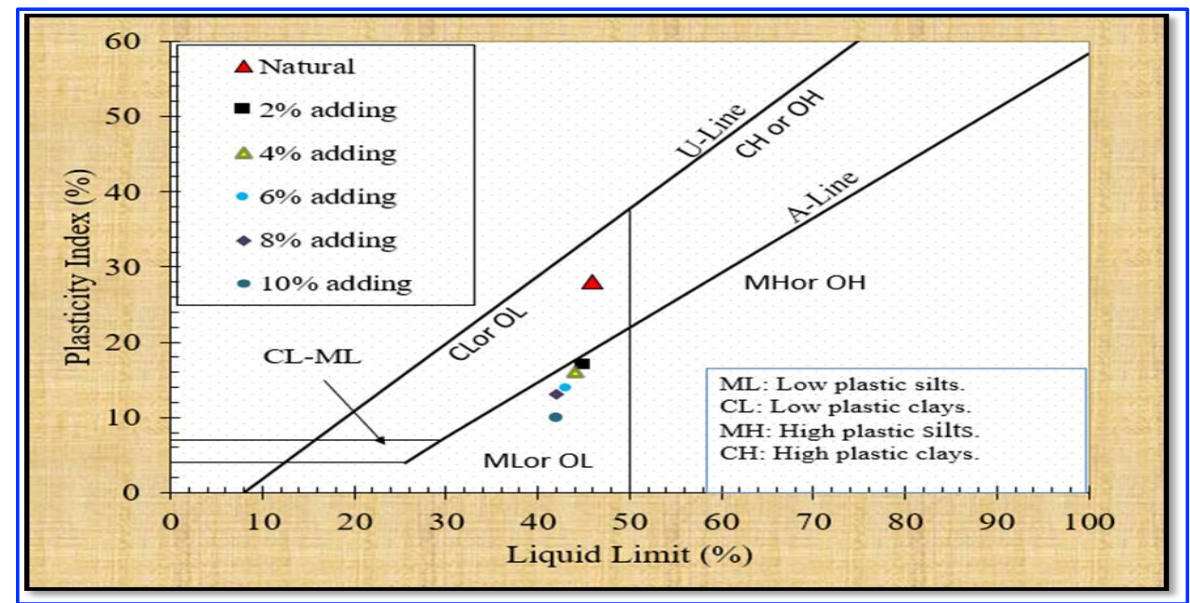

Fig. 3. Soil classification of West Qurna Oilfield site soil according to plasticity diagram before and after adding crude oil

\subsection{Consolidation}

The consolidation test results of the cohesion soil sample from West Qurna oilfield site that performed according to ASTM D-2435 are illustrated in Figure 4. The results display that the value of the compression index $\left(\mathrm{C}_{\mathrm{c}}\right)$ for the natural sample free of additives is $0.10 \%$, while when adding $2 \%$ and $10 \%$ of the crude oil, it increased to $0.17 \%$ and $0.30 \%$ respectively. Furthermore, the swelling index $\left(\mathrm{C}_{\mathrm{r}}\right)$ 
for the natural sample is $0.013 \%$, but it increased to $0.027 \%$ and $0.033 \%$ when adding crude oil of $4 \%$ and $6 \%$ respectively (Fig. 5).

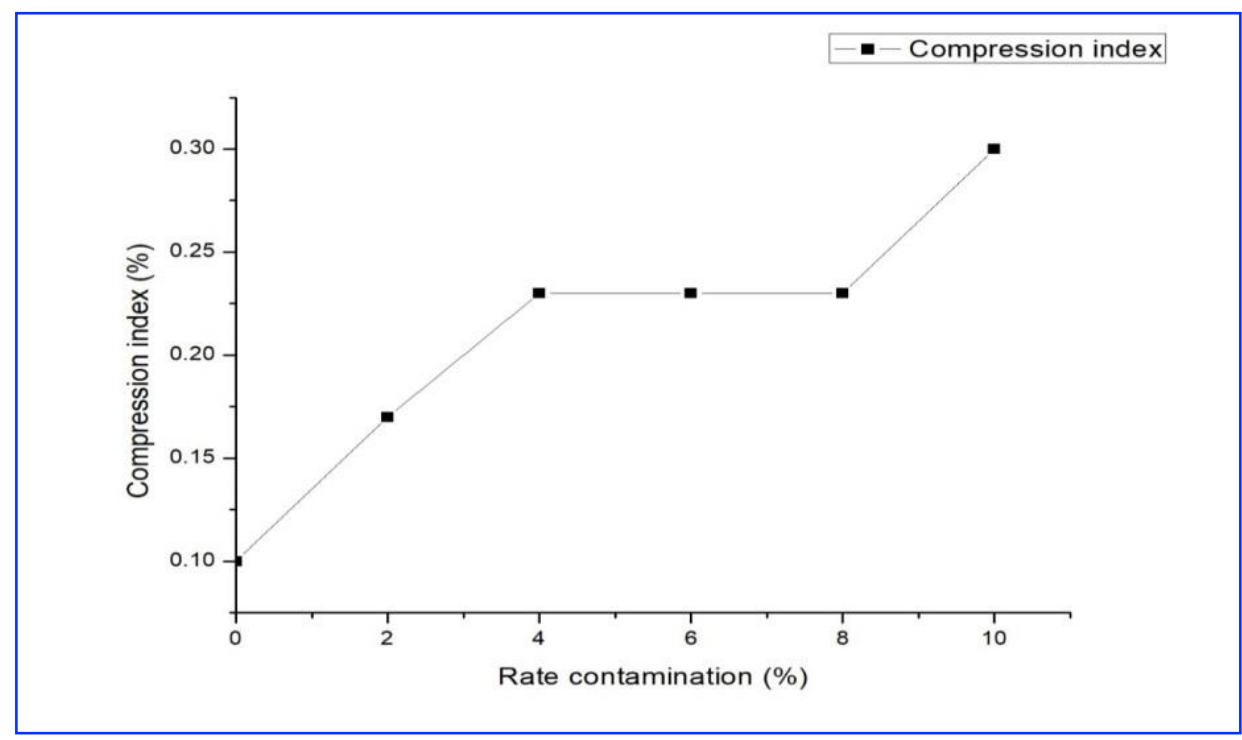

Fig. 4. The values of compression of West Qurna oilfield site soil before and after adding crude oil

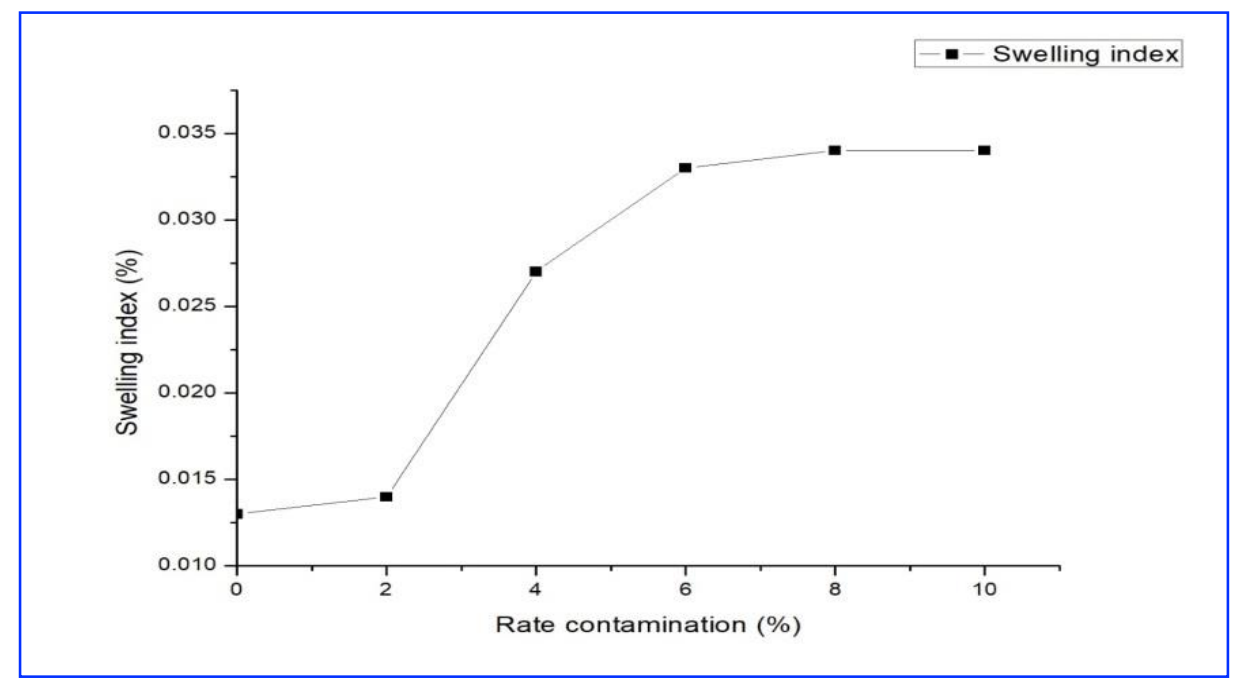

Fig. 5. The values of swelling index of West Qurna oilfield site soil before and after adding crude oil

The pre-consolidation pressure $\left(\mathrm{P}_{c}\right)$ after addition of crude oil found increase. The value for this pressure is $70 \mathrm{kN} / \mathrm{m}^{2}$ in natural soil, while it increases to 95 and $120 \mathrm{kN} / \mathrm{m}^{2}$ after adding $4 \%$ and $8 \%$ of crude oil, respectively (Fig. 6). The results also show that the coefficient of consolidation $\left(\mathrm{C}_{\mathrm{v}}\right)$ increases when adding crude oil. The coefficient of consolidation for natural soil sample is $8.61 \mathrm{~m}^{2} /$ year. But it increased to $14.12 \mathrm{~m}^{2} /$ year and $22.5 \mathrm{~m} 2 /$ year after adding the crude oil of $2 \%$ and $10 \%$, respectively (Fig. 7). The presence of crude oil in the soil increases the values of the consolidation coefficients and the rates of settlement will increase. This increase is due to the major change in soil structure as a result of the interaction between clay minerals and oil, which reduces the repulsion force between the clay particles. The presence of crude oil makes the soil structure compressible. 


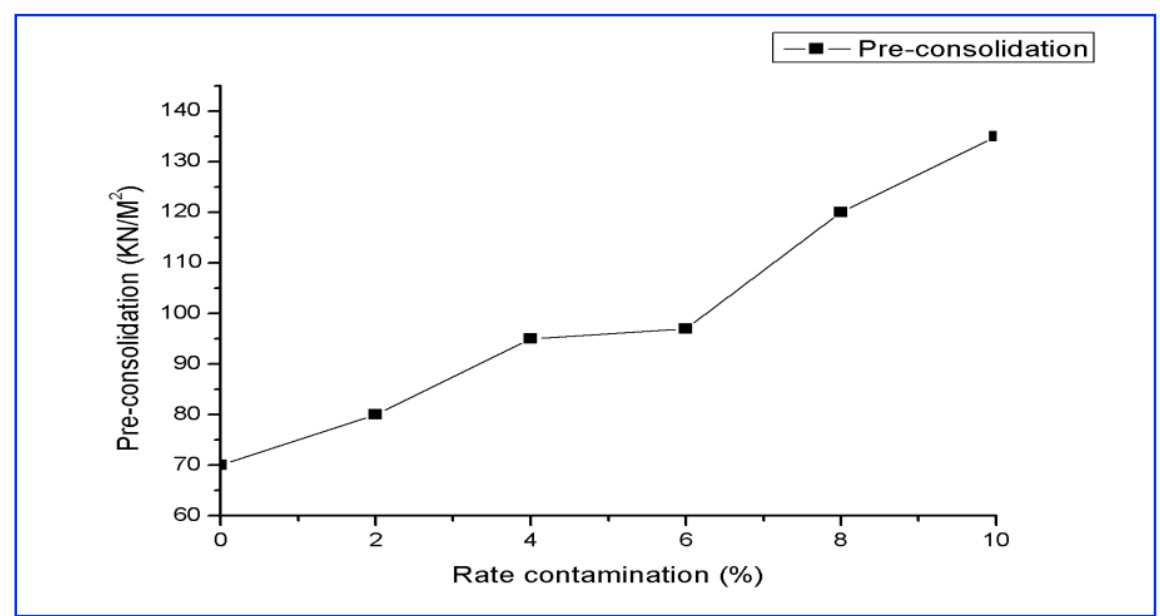

Fig. 6. The values of pre-consolidation pressure of West Qurna oilfield site soil before and after adding crude oil

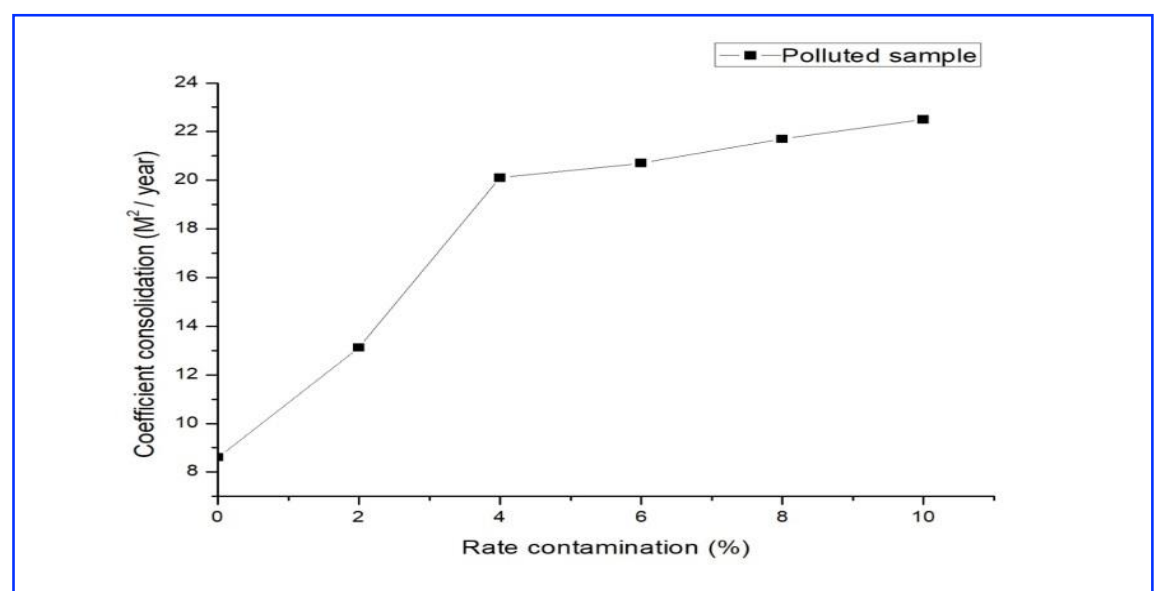

Fig.7. The values of coefficient of consolidation of West Qurna oilfield site soil before and after adding crude oil

\subsection{Unconfined Compressive Strength}

The test results indicate a decrease in the unconfined compressive strength with an increase in the crude oil content as shown in Fig. 8. The compressive strength of natural soils is $25 \mathrm{kN} / \mathrm{m}^{2}$, and it has been observed that adding $2 \%$ of crude oil reduces the values of unconfined compressive strength to 20 $\mathrm{kN} / \mathrm{m}^{2}$, and it gradually decreases with the increase of the oil content. The compressive strength value is $18 \mathrm{kN} / \mathrm{m}^{2}$ when adding $4 \%, 10 \mathrm{kN} / \mathrm{m}^{2}$ when adding $10 \%$ of crude oil. The presence of crude oil in the soil acts as a lubricant material and leads to reduce interaction between soil particles that helps them to slip over each other and reduce cohesion and internal friction

\subsection{Rapid Absorption Test}

From Fig. 9 can be seen that the natural soil sample has an absorption capacity of 30.8\%. A large percentage is attributed to the cohesion nature of the soil and its ability to retain water. Adding the crude oil to the soil, lead to the absorption that decreased and reached a value of $10.6 \%$ when adding $2 \%$ of crude oil, while adding $10 \%$ the absorption significantly decreased to a value of $1.05 \%$. The decrease in water absorption of the sample is caused by the fact that the oil is surrounded and enveloped the sample and blocked the soil voids which all lead to reduce the water absorption as the oil became an insulating material between the soil and water particles. 


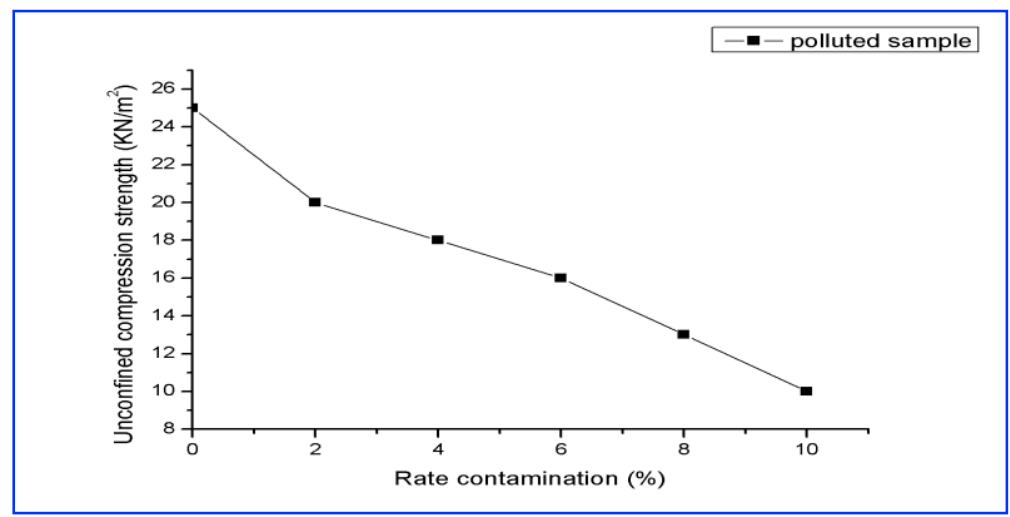

Fig. 8. The values of unconfined compressive strength of west Qurna oilfield site soil before and after adding crude oil

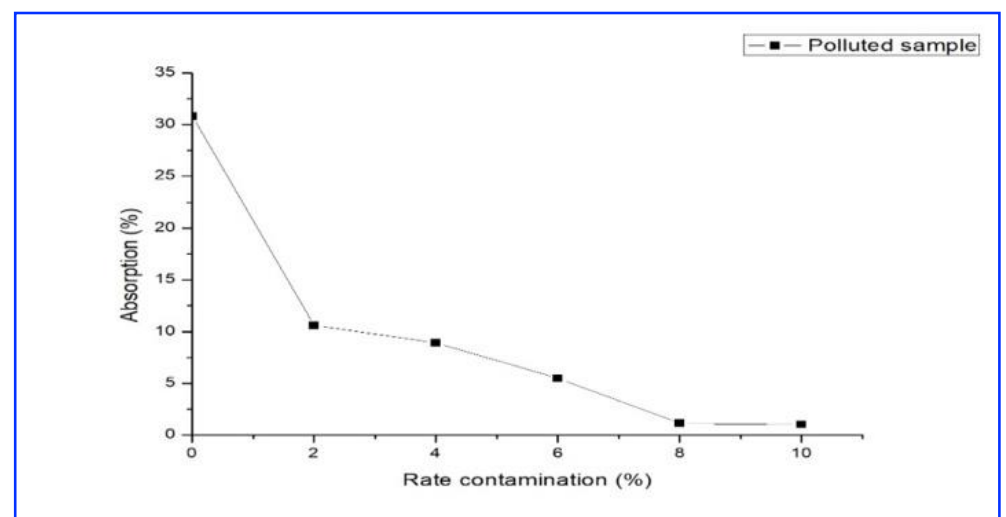

Fig. 9. The values of absorption of west Qurna oilfield site soil before and after adding crude oil

\section{Conclusions}

According to the result of the geotechnical properties of the soil study, the following conclusions can be drawn: The soil in the site at West Qurna oilfield is classify as clayey silt with little sand. The values of liquid limit, plasticity index, unconfined compressive strength and absorption gradually decreased with increase in the percentages of added crude oil. The values of compression index, swelling index, pre-consolidation pressure, and coefficient of consolidation are gradually increased with increasing proportions of added crude oil. Accordingly, oil contamination has a negative effect on the geotechnical properties of soils.

\section{Acknowledgements}

The authors are very grateful to the Editor in Chief Prof. Dr. Salih M. Awadh, the Secretary of Journal Mr. Samir R. Hijab and the Technical Editors Dr. Heba S. Al-Mimar for their great efforts and valuable comments.

\section{References}

Akinwumi, I., Diwa, D., and Obianigwe, N., 2014. Effects of crude oil contamination on the index properties, strength and permeability of lateritic clay. International Journal of Applied Sciences and Engineering Research, 3(4), 816-824.

Al-Amoudi, O.S., and Abduljauwad, S. N., 1995. Strength characteristics of sabkha soils. Geotechnical Engineering, 26(1), 73-92. 
Alhassan, H. M., and Fagge, S. A., 2013. Effects of crude oil, low point pour fuel oil and vacuum gas oil contamination on the geotechnical properties sand, clay and laterite soils. International Journal of Engineering Researches, 3(1), 1947-1954.

Al-Jaberi, M. and Mahdi, M., 2020. Mineralogy and paleontology of the quaternary sediments in Karmat Ali at Basrah, southern Iraq. Iraqi Geological Journal, 53 (2C),105-120.

Al-Khalf, N., and Al-Saad, H., 2019. Mineralogy and geochemistry of recent sediments in Basrah, southern Iraq. Iraqi Geological Journal, 52, (1): 40-52.

Al-Mimar, H.S., Awadh, S.M., Al-Yaseri, A.A. and Yaseen, Z.M., 2018. Sedimentary units-layering system and depositional model of the carbonate Mishrif reservoir in Rumaila oilfield, Southern Iraq. Modeling Earth Systems and Environment, 4(4), 1449-1465.

Al-Sanad, H.A., Eid, W.K., and Ismael, N.F., 1995. Geotechnical properties of oil-contaminated Kuwaiti sand. Journal of Geotechnical Engineering, 121, 407-416.

ASTM D-1833- 99. Standard test method for California bearing ratio of laboratory-compacted soils.

ASTM D-2166. Standard test method for unconfined compressive strength of cohesive soil.

ASTM D-2435. 2011. Standard test methods for one-dimensional consolidation properties of soils using incremental loading.

ASTM D-421 and D-422. 2002. Standard test for particle size analysis of soil.

ASTM D-4318. 2005. Standard test methods for liquid limit, plastic limit, and plasticity index of soils.

Awadeesian, A.M., Al-Jawad, S.N., Awadh, S.M. and Al-Maliki, M.M., 2018. Chronostratigraphically based reservoir model for Cenomanian carbonates, southeastern Iraq oilfields. The Iraqi Geological Journal, 127.

Awadh, S.M., 2015. Cd, Ni, and Pb distribution and pollution assessment in roadside dust from Baghdad City and Western Iraqi Desert. Arabian Journal of Geosciences, 8(1),.315-323.

Awadh, S.M., Al-Mimar, H.S. and Al-Yaseri, A.A., 2018. Salinity mapping model and brine chemistry of Mishrif reservoir in Basrah oilfields, Southern Iraq. Arabian Journal of Geosciences, 11(18), 1-12.

Breivik, E.C., and Burgess, L.C., 2013. Soils and human health. Boca Raton. CRC Press, 59-80.

British Standard Institutions 1377: 1975 - 1990. Methods of testing soil for civil engineering purposes.

Hahn, I., 2005. Summary report-former MGP operations and dense non-Aqueous phase liquid occurrence. HAI Project No.2708, NW Natural, Portland, Oregon.

Hassan, H., Taha, R., Al-Rawas, A., Al-Shandoudi, B., Al-Gheithi,A. and Barami, A., 2005. Potential uses of petroleum- contaminated soil in highway construction. Construction and Building Materials, 19(8), 646652.

Jamal, A., and Shahalam, A., 2002. Water infiltration through diesel-contaminated soil, Journal of Environmental Science and Health, 37(6), 1041 - 1049.

Kermani, M., and Ebadi, T., 2012. The effect of oil contamination on the geotechnical properties of fine-grained soils. International Journal of Soil Sediment Contamination, 21, 655-671.

Luan,V., Thi Nu, N., and Toan, D., 2021. Consolidation properties of Ho Chi Minh City soil, Vietnam. Iraqi Geological Journal, 54 (1A), 1-10.

Meegoda, N., and Ratnaweera, P., 1994. Compressibility of contaminated fine- grained soils. Geotechnical Testing Journal, 17(1), 101-112.

Nazir, A., 2011. Effect of motor oil contamination on geotechnical properties of over consolidated clay. Alexandria Engineering Journal, 50(4), 331-335.

Rahman, Z., Umar, H., and Ahmad, N., 2010. Geotechnical characteristics of oil-contaminated granitic and metasedimentary soils. Asian Journal of Applied Sciences, 3(4), 237-249.

Sanjay, J., Shroff, A., Jignesh, V., Tiwari, K. and Ramakrishnan, D., 2003. Stabilization of fuel oil contaminated soil-A case stydy. Journal of Geotechnical and Geological Engineering, 21, 415-427.

Scott, R.T.1968. Principle of soil mechanics, Addison-Wesley, Reading Massachusetts, 406 pp.

Seed, H., Mitchell, T. and Cham, C. 1962. Study of swell and swell pressure characteristic of clay. Highways Research Board, Bulletin, 313, 12 -39. 